\title{
The Impact of Inflation in 90-ies on the Development of Economy in Russia
}

\author{
Askar N. Mustafin ${ }^{1}$, Margarita N. Maksimova ${ }^{2}$ \\ 1, 2 Kazan Federal University, Institute of Management, Economics and Finance, Assistant Lecturer of the Department \\ of the Economic Theory, ${ }^{1}$ mustafin.ksu@yandex.ru, ${ }^{2}$ soc90@ mail.ru
}

\section{Received: 21st October 2017 Accepted: 16th November 2017, Published: 31st December 2017}

\begin{abstract}
The sixtieth anniversary of the socialist system in Russia did not pass without traces for the economy of the Russian Federation, which was nascent in the 1990s. Strict regulation of economic processes by the state in the USSR had a number of positive consequences, but closer to the mid-60s of the 20th century it could not adapt to the realities and requirements of the world economy. The beginning of the 50's and 60's can be considered the time of the birth of inflation in Russia, which was associated with a sharp drop in social production. Since the prices were fixed, inflation had a hidden character and its rates were held back. The socio-economic consequences of inflation have led to the stagnation of the economy in Russia up to the 2000s, and the term "social" is ahead for a reason, since the main negative effect of inflation is the redistribution of income and wealth in the country. The ongoing processes contributed to the gradual process of transition from a command economy to a market economy. Thus, the outwardly stable and prosperous Soviet state concealed behind its facade suppressed inflation and unemployment, which eventually pushed the indefinite development of the market economy in the Russian Federation.
\end{abstract}

Keywords: Inflation, Crisis, Social and Economic Consequences, Import Substitution, Anti-inflationary Policy.

\section{Introduction}

At the present stage of the development of the Russian economy one of its main tasks is transition to an innovative model of development [1]. Inflation has a direct impact on innovative development, since its indicators and socio-economic consequences have a negative effect on the economic security of a country.

Inflation is accompanied by a depreciation of money and is manifested in relation to goods, gold and foreign currency. Thus, inflation occurs in the sphere of money circulation, but its primary cause is disproportions in the reproduction process. Therefore, the state of monetary circulation in a country can be considered a barometer of its economic and political life.
The negative social and economic consequences of inflation compel the state being concerned to pursue a certain economic policy, with considerable attention paid to the regulation of the money supply. Antiinflationary policy has a rich assortment of various monetary and fiscal measures, tax measures and stabilization programs for regulating and distributing incomes.

\section{Methods}

The research methodology is presented by methods of comparative macroeconomic analysis, synthesis, connection of historical and logical matters, normative and positive analysis.

\section{Results}

Political and social processes of the 1990s did not pass without traces for the market economy of Russia and in January 1992 there was an open explosion of inflation caused by the introduction of free pricing. Radical liberalization of consumer prices was carried out on January 2, 1992 in accordance with the Decree of the President of the RSFSR dated 03. 12. 1991 N 297 "On measures to liberalize prices" and the Decree of the Government of the RSFSR dated December 19, 1991 No. 55 "On measures to liberalize prices", which led to liberation of $90 \%$ of retail and $80 \%$ of wholesale prices for goods [2, 3]. Since that moment, enterprises have begun to sharply raise prices for their goods by an average of 5 times. At the same time, there was a liberalization of wages, and free retail trade is allowed. Therefore, the growth of nominal wages during this period begins to lag behind the growth of prices, which ultimately leads to a decrease in the well-being of citizens in the 90s, and in the future will cause the emergence of "penniless millionaires". A member of the public was forced to spend all his or her income only for essential goods, the prices for which quickly began to approach the world ones. Prices freed from state control literally skyrocketed. Already in the first years of reforms, they increased by $2509 \%$ compared with 1991, then the same rates continued to gain momentum: in 1993 they grew 9. 4 times, in 1994 3.2, and in 1995 they were 2. 3 times higher than the year before [4]. 
Helix Vol. 8(1): 2430- 2434

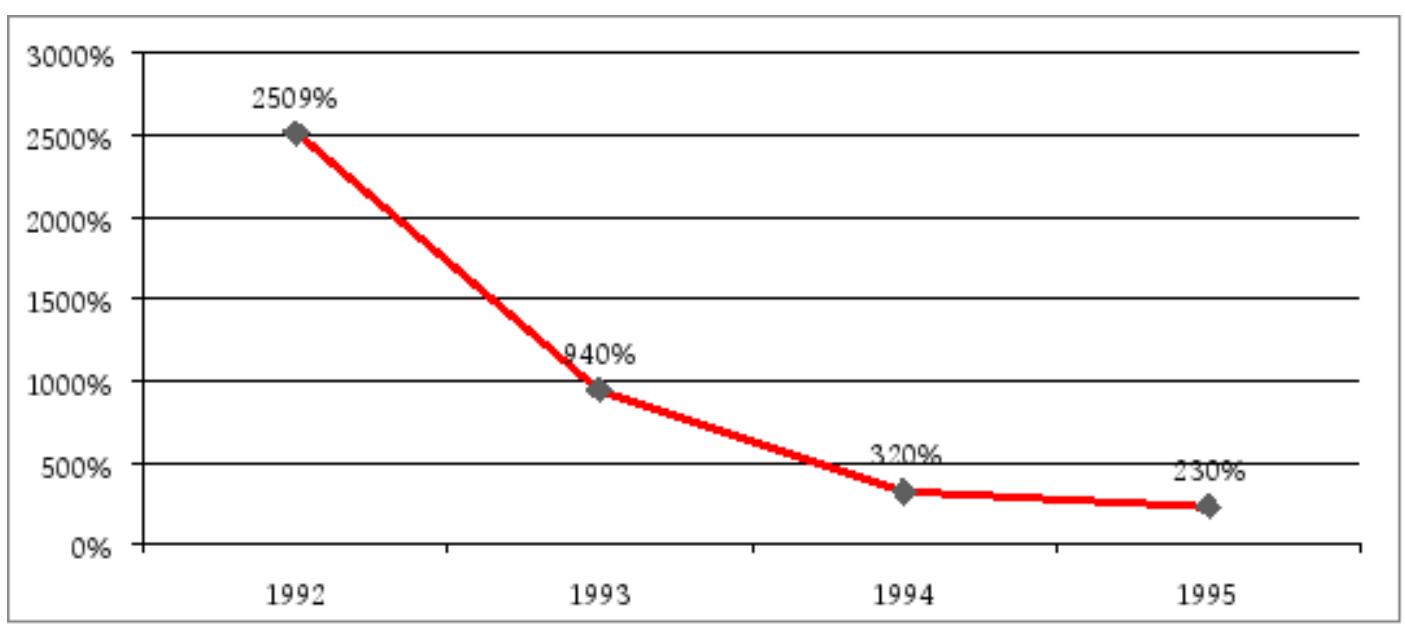

Figure 1.The Rate of Inflation from 1992 to 1995.

The Central Bank's decision to grant loans to enterprises and former Soviet republics had a big impact on the inflation jump; that was achieved by issuing money to cover the budget deficit [5]. This led to a depreciation of the deposits invested during the Soviet period, which is reflected in the population's distrust of the banking system and the national currency at the present time. So by 2000 about $40 \%$ of deposits of citizens accounted for the share of savings in foreign currency [6]. According to polls of citizens in 2017, 49\% of retirement age people refrain from making deposits in banks due to the danger of depreciation of their savings. A survey of the male population showed that only $56 \%$ of respondents are ready to cooperate with financial institutions, and only $61 \%$ among the female representatives are trusted in the banking system. These indicators are evidence that the mistrust of banks in our country is still at a high level. Therefore, during the currency crisis in Russia in 2014-2015, "the panic was, in many respects, a psychological underpinning: many investors immediately recalled the crises of the 1990s," says Boris Abelev, senior vice president of the investment company TN-Capital [7].

Since 1996, the inflation rate has gradually decreased to the mark of $100 \%$. By 1997, it reached the level of $11 \%$, so the population had a hope of stabilizing the Russian economy. However, the situation deteriorated sharply in 1998, when the government defaulted on its financial obligations due to the financial crisis. The subsequent massive outflow of capital from Russia led to the devaluation of the ruble, as a result of which prices for goods and services in the markets increased significantly.

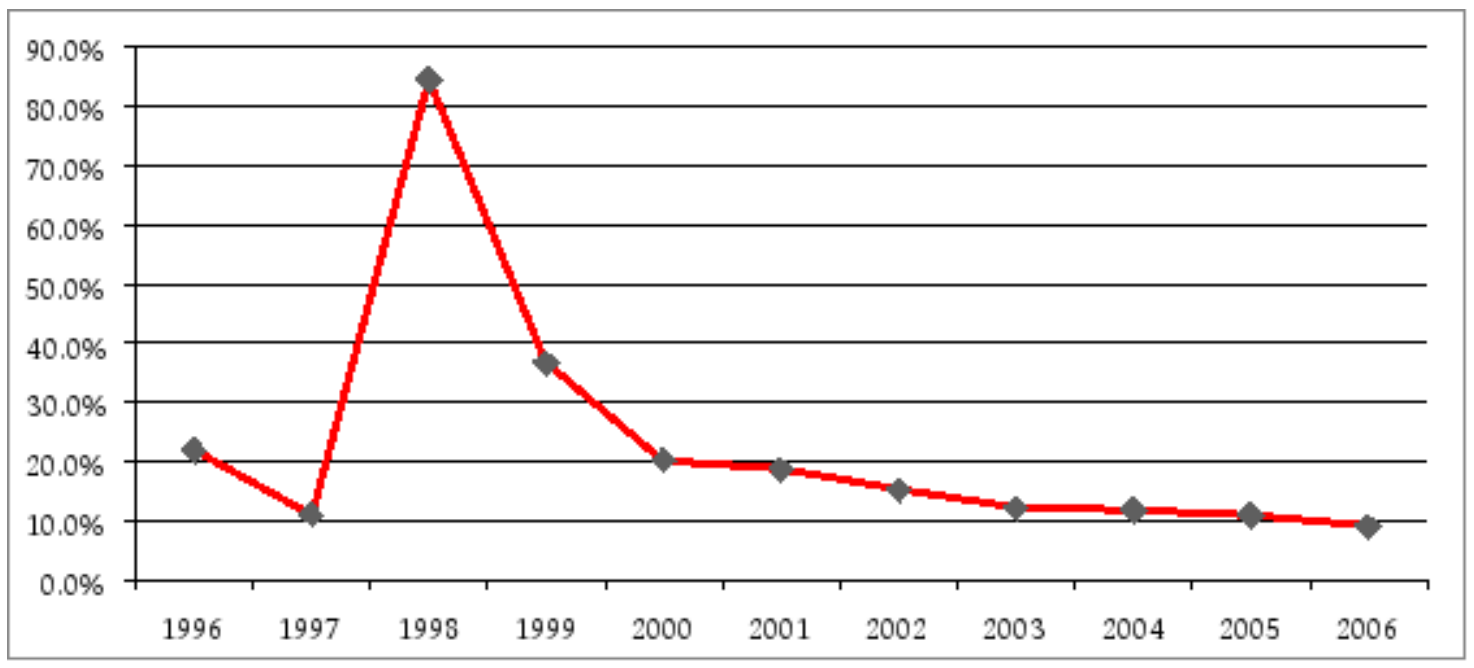

Figure 2.The Rate of Inflation from 1996 to 2006

However, a sharp jump in prices gave impetus to import substitution in Russia. By 1998, the volume of imports decreased by $20 \%$, and by 1999 it went down by another $28 \%$. In this way, the import substitution caused by the devaluation became a positive factor for the development of the economy; especially it had a big influence on the development of the manufacturing industry in 1998-2000. In subsequent years, the government only supported the evolvement of Russian industry, and from this it can be concluded that it was 
the inflation of the 1990s that put forward the problem of the need for an import substitution policy.

In the 2000s, the share of imported food reached $40 \%$ in the country, and in Moscow - 70\%; i.e. it almost tripled the threshold of economic security, which was particularly evident in the growth of food prices in 2007. The government was aware that it was impossible to allow further development of such a situation, as a result of which the import substitution policy was being implemented in Russia. After the introduction of sanctions against Russia in 2014, this policy only expanded the range of its tasks and activities. Measures on import substitution have given a definite result. If we consider the dynamics of changes in the share of imports of individual goods in their commodity resources in 2015-2016, then we can conclude that this figure is reduced in all production categories (Table 1) [8].

Table 1.The Share of Imports of Individual Goods in the Corresponding Commodity Groups in 2015-2016.

\begin{tabular}{|c|c|c|c|c|}
\hline \multirow{2}{*}{} & \multicolumn{2}{|c|}{2015} & 2016 \\
\cline { 2 - 5 } & $\begin{array}{c}\text { January - } \\
\text { March }\end{array}$ & January -June & $\begin{array}{c}\text { January- } \\
\text { September }\end{array}$ & January - June \\
\hline Meat and poultry, including by-products & 9.6 & 11.6 & 13.4 & 10.6 \\
\hline Animal oil & 22.3 & 24.5 & 25.5 & 23.8 \\
\hline Cheeses & 21.6 & 22.5 & 22.6 & 24.2 \\
\hline Flour & 0.4 & 0.5 & 0.6 & 2.1 \\
\hline Groats & 0.2 & 0.2 & 0.3 & 0.1 \\
\hline Vegetable oils & 14.6 & 14.5 & 17.5 & 16.0 \\
\hline Milk powder and cream & 57.0 & 58.0 & 54.0 & 60.2 \\
\hline
\end{tabular}

Inflation caused by imbalances in the main sectors of the national economy of the Russian Federation and exacerbated by state economic policy based on the concepts of ultra-liberal monetarism led to a whole range of socio-economic problems in the country. Transformation of the socio-economic structure of society against the background of the crisis at the early 90 'swas heavily endured by most of the country's population, current real incomes and consumer savings decreased substantially. These factors have led to a significant increase in poverty and the proportion of low-income families. Despite the fact that the economic crisis occurred at the dawn of the formation of the modern Russian economy, it cannot be said that there has been a positive trend in the change in the social structure of society at the moment. As shown in Figure 3, the materials of the sample survey of household budgets allow us to conclude that the share of the poor people in Russia living in cities is quite high and has been keeping at a level of $60 \%$ for almost 10 years (2006-2014) with minor deviations. The share of the poor people living in rural settlements mostly varies about $40 \%$, with a tendency to increase this indicator, which is due not only to inflationary influence, but also to the process of urbanization.

\section{The share of low-income families in the structure of Russian society, percents}

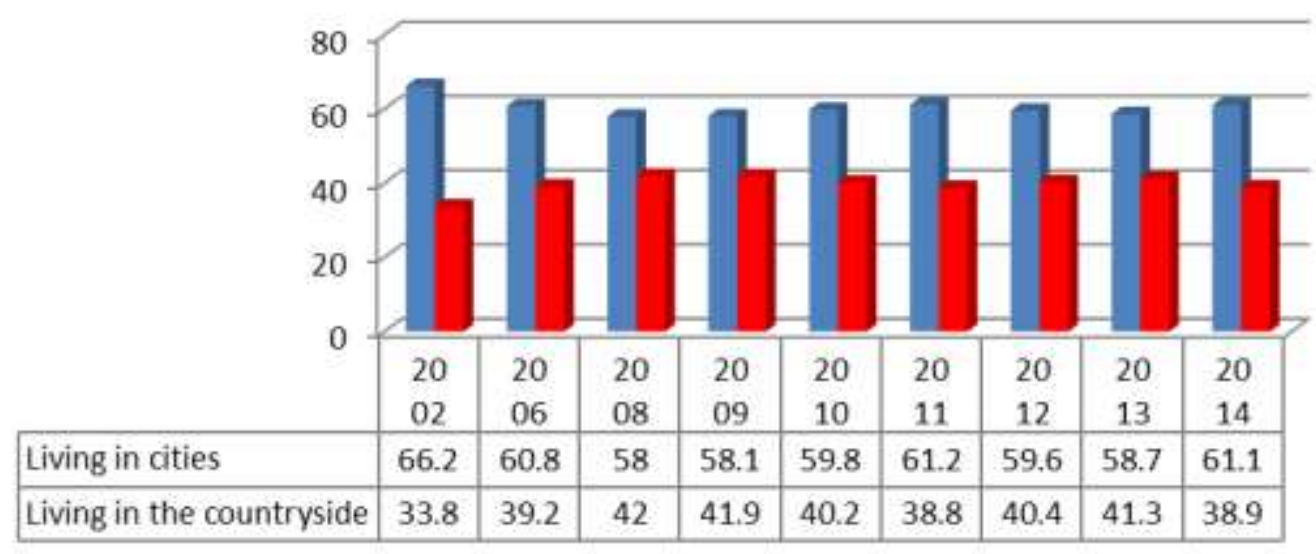

Figure 3 Share of Low-Income Families in the Structure of Russian Society. 
Inflation had an immediate impact on the monetary policy of the Central Bank of Russia. In connection with inflationary processes, the Central Bank raised interest rates to reduce the amount of money supply and prevent further growth of inflation. Especially this influence is noticeable during periods of depression in the economy. In 2008-2009, during the global financial crisis, the growth of inflation caused an increase in interest rates, and during the next economic crisis in 2014, the interest rate reached its maximum in the history of the Russian economy and amounted to $17 \%$. In recent years, there has been a reform of the banking system in the Russian Federation, and a key interest rate became the economic and financial instrument in the area of the monetary and credit policy of the state. This is the minimum interest rate at which the Central Bank of Russia (CBR) lends to commercial banks for a period of 1 week, and at the same time this is the maximum rate at which the CBR is willing to accept cash from banks for deposits. Since March 2015, there has been a steady decline in the key interest rate, in the period from 02.02 .2015 to 15.03 .2015 it was $15.0 \%$ per annum, at the current moment the key interest rate is $9.75 \%$ per annum [9]. It is worth noting that the lowering of the key interest rate indicates a reduction in the rate of inflation in the country.

Inflation also has a negative effect on the process of introducing new technologies into production; this is explained by the fact that from the point of view of an entrepreneur, the production costs associated with wages increase more slowly than the costs of acquiring the means of production. An outstripping rise in prices leads to the fact that the use of old labor-consuming technologies proves to be more profitable than the introduction of modernized technology. Modernization and innovative development of the economy are two interrelated sides of the process of sustainable economic development [10]. The data of the Federal State Statistics Service in Figure 4 show that half of the equipment $(49 \%)$ is in operation for more than $5-15$ years, and $12 \%$ of enterprises use machines older than 30 years [11].

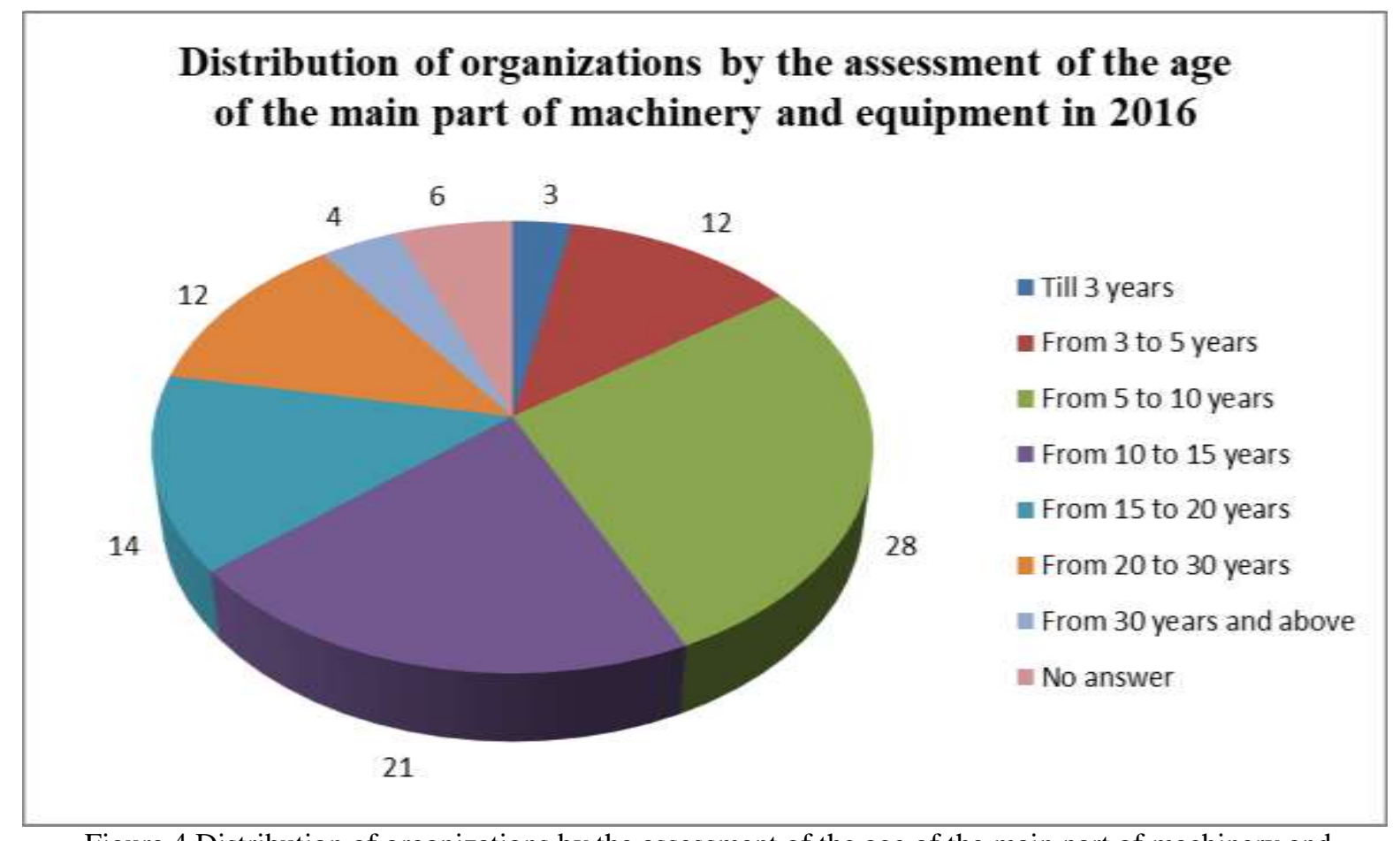

Figure 4.Distribution of organizations by the assessment of the age of the main part of machinery and equipment in 2016

These figures make it possible to make sure that production in the country really lags behind in terms of introducing the achievements of world scientific and technological progress. Therefore, we believe that the Russian economy as a whole and it's regions in particular need to search for new management, organizational solutions, which are based on a systematic approach to innovative modernization and new management mechanisms, naturally built into all types of innovative processes of economic life in the center and in places [12].

\section{Conclusions}

Inflation in the 1990s had a significant impact on the emerging of market economy in Russia. First, as a result of inflation, there was a deformation of the market mechanism. Unjustified price growth has led to a distortion of information about the real structure of production and consumption in the country. That is, the 
market mechanism has stopped to provide producers with the right signals for investment, and the disorientation of investments has inevitably led to sectoral and regional imbalances. Secondly, inflation slowed down the process of introducing new high-tech technologies into production, thereby slowing down the scientific and technological progress, while simultaneously increasing the gap from the leading countries. Thirdly, it became much harder to predict changes in prices and costs, and efficiency from financial investments as a result of inflation, and as the consequence, for many years the manufacturers began to make large investments in production with caution and risk, what led to a general slowdown and stagnation of economic development in Russia.

\section{Summary}

In view of the fact that inflation processes affect practically all branches of the national economy and the social situation in the country as a whole, they do not remain without the attention of the government. The state conducts an active anti-inflationary policy. The mechanisms of influence on pricing play a leading role in the complex of anti-inflation measures implemented by the Government of the Russian Federation. First, they include limiting the growth of regulated prices for products of natural monopolies and tariffs for utility services in the face of increased control over the costs of monopolies. Secondly, the anti-inflation package includes a reduction in the growth rate of prices for fuels and lubricants by encouraging competition, developing exchange trade, reducing the tax burden and technological renewal of the oil industry. Thirdly, an important element of antiinflationary policy is the slowdown in the growth of prices for food products against the stimulating the supply of these goods and improving the regulation of their imports.

\section{Acknowledgments}

The work is carried out in accordance with the Federal Government Program of Competitive Growth of Kazan Federal University.

\section{References}

1. Akhmetshina E. R., Mustafin A. N., Public-private partnership as a tool for development of innovative economy//INTERNATIONAL CONFERENCE ON APPLIED ECONOMICS (ICOAE) 2015. - Procedia Economics and Finance. - 2015. - Vol.24, Is.. - P.3540.

2. Decree of the President of the RSFSR dated 03.12.1991 N 297 (edition dated 28. 02. 1995) "On measures for the liberalization of prices".

3. Decree of the Government of the RSFSR dated December 19, 1991 No. 55 (edition of 26.06.1995, as amended on 14.06.2001) "On measures to liberalize prices".
4. Inflation in Russia [Digital source]. - Access mode: http://www. grandars. ru/student/ekonomicheskayateoriya/inflyaciya-v-rossii. html.

5. Sulakshin S. S. From the USSR to the Russian Federation: results and lessons / Sulakshin S.S., Vilisov M.V., Kara-Murza S.G., Leksin V.N., Zachesova Yu. A. / Materials of the All-Russian Scientific Conference (Moscow, November 25, 2011). - 2012. - P. 177.

6. From under the milestones: Banks and trust [Digital source]. - Access mode: https://www. vedomosti. ru/opinion/articles/2007/01/22/iz-pod-veh-banki-idoverie.

7. Crisis of faith [Digital source]. Access mode: http://www. banki. ru/news/daytheme/?id=8488149.

8. Indicators characterizing import substitution in Russia [Digital source]. - Access mode: http://www.gks.ru/wps/wcm/connect/rosstat_main/ross tat/ru/statistics/importexchange/\#.

9. Official site of the Central Bank of Russia [Digital source]. - Access mode: http://www. cbr. ru/press/pr. aspx?file $=24032017$ 132958keyrate2017-03-

24T13 25 44. htm.

10. Mustafin A.N., Incentives and factors affecting the improvement of the human capital quality in the innovative economy//Journal of Economics and Economic Education Research. - 2016. - Vol.17, Is.SpecialIssue2. - P.128-137

11. Distribution of organizations by estimating the age of the main part of machinery and equipment in 2016 [Digital source]. - Access mode: http://www. gks. $\mathrm{ru} / \mathrm{free}$ doc/new_site/business/invest/Graf-iap. htm.

12. Mustafin A.N, Gira M.D., Features of Russian economy in the context of innovative modernization and increasing role of human capital//Academy of Strategic Management Journal. - 2016. - Vol.15, Is.Speciallssue2. - P.71-75. 